\title{
Evaluasi Karakter Organ Generatif Tanaman \\ Tomat (Solanum lycopersicum L.) \\ Secara Hidroponik
}

\author{
Evaluation of Generative Organ Characteristics \\ of Solanum lycopersicum L. \\ Hydroponically
}

\author{
Zurrahmi Wirda, Elvira S. D, dan Mira Agustina \\ Program Studi Agroekoteknologi, Fakultas Pertanian, Universitas Malikussaleh \\ Kampus Cot Teungku Nie, Reuleut, Muara Batu, Aceh Utara 24355, Indonesia \\ Email:
}

Diterima 22 Juli 2014; Dipublikasi 1 September 2014

\begin{abstract}
Abstrak
Buah tomat merupakan jenis sayuran yang mengandung nutrisi yang tinggi. Ketika tanaman memasuki fase generatif akan terjadi beberapa perubahan fisik, biokimia dan fisiologis terutama terhadap buahnya. Penelitian ini bertujuan untuk mengetahui pengaruh varietas dan media tanam terhadap karakter organorgan generatif tanaman tomat yang ditanam secara hidroponik. Hasil penelitian menunjukkan bahwa varietas Victory memberikan jumlah dompolan per tanaman, jumlah bunga per dompolan dan jumlah buah per dompolan terbanyak, namun varietas Tombatu F1 memiliki diameter buah, panjang buah dan berat buah persatuan terbaik. Media tanam yang digunakan tidak memberikan pengaruh terhadap karakter organ-organ generatif tanaman tomat yang diamati.
\end{abstract}

Kata kunci: organ generative, tomat, hydroponic, varietas, media tumbuh

\begin{abstract}
Tomato is a type of vegetable which highly nutrition contain. When the plant reach generative stage, it experiences physical, biochemical and physiological change especially on the fruit. The purpose of the study was to evaluate the effect of varieties and growth media on characters of generative organ hydroponically. The result showed Victory variety have more fruit branch on each plant, more flower on fruit branch and more fruit on each fruit branch. However, Tombatu variety showed wider fruit diameter, longer fuit length and havier fruit weight. Growth media showed no significant effect on variables observed.
\end{abstract}

Keywords : generative organ, tomato, hydroponic, varieties, growth media

\section{Pendahuluan}

Masyarakat mulai menyadari bahwa sayuran dan buah yang beredar di pasar sekarang ini telah tercemar residu pestisida, tidak terkecuali tomat. Berawal dari kesadaran ini orang mulai memilih produk yang berkualitas dan bebas residu berbahaya walaupun harus membayar sedikit lebih mahal. Kebutuhan konsumen akan produk yang berkualitas tersebut dapat dipenuhi dengan mem-budidayakannya dalam lingkungan terkendali dengan memanfaatkan teknologi hidroponik.

Terbatasnya lahan produktif saat ini tidak lagi menjadi kendala dalam mengusahakan pertanian indoor maupun outdoor. Meskipun sistem hidroponik bukan teknologi baru lagi bagi kita, namun justru kini telah menjadi trend takkala media tanah yang produktif semakin berkurang. Selain tidak memakan tempat yang luas, juga mudah perawatannya serta lebih menguntungkan karena tanaman bebas dari gangguan hama dan penyakit yang berada dalam tanah dan masih banyak lagi keuntungan dari sistem hidroponik (Trisnawati dan Setiawan, 2005).

Buah tomat saat ini merupakan salah satu komoditas hortikultura yang bernilai ekonomi tinggi dan masih memerlukan penanganan serius, terutama dalam hal peningkatan hasilnya dan 
kualitas buahnya. Apabila dilihat dari rata-rata produksinya, ternyata produksi tomat di Aceh pada tahun 2013 masih rendah, yaitu 34.846 ton jika dibandingkan dengan provinsi tetangga yaitu Sumatra Utara yang mencapai 114.168 ton (Kementan, 2013). Rendahnya produksi tomat di Aceh kemungkinan disebabkan varietas yang ditanam tidak cocok, kultur teknis yang kurang baik atau pemberantasan hama/penyakit yang kurang efisien.

Produksi tomat tersebut sebenarnya masih dapat ditingkatkan dengan ditemukannya varietas-varietas unggul baru dan hibrida yang berproduksi tinggi, tahan hama dan penyakit, dan melalui penerapan budidaya yang benar. Hingga tahun 2006, ada sebanyak 54 varietas tomat yang telah dilepas oleh Menteri Pertanian dan varietas yang sudah dilepas tersebut merupakan varietas anjuran (Direktorat Perbenihan dan Sarana Produksi, 2010), dimana setiap varietas memiliki karakter yang berbeda.

Media tanam merupakan salah satu faktor penting dalam hidroponik. Selain dengan media air, bertanam secara hidroponik juga menggunakan media-media lain selain tanah. Persyaratan terpenting untuk media hidroponik harus ringan dan porous. Tiap media mempunyai bobot dan porositas yang berbeda. Oleh karena itu, dalam memilih media sebaiknya dicari yang paling ringan dan mempunyai porositas yang baik (Prihmantora dan Indriani, 2005).

Penelitian ini bertujuan untuk mengetahui pengaruh varietas dan media tanam terhadap karakter organ-organ generatif tanaman tomat yang ditanam secara hidroponik.

\section{Metode Penelitian}

Penelitian ini dilaksanakan di Komplek Stasiun Meteorologi Lhokseumawe, Desa Panigah Kecamatan Muara Batu Kabupaten Aceh Utara dengan elevasi 27 meter dpl. Penelitian ini dilakukan dari bulan Oktober 2012 sampai dengan Maret 2013. Bahan-bahan yang digunakan adalah benih tomat dari varietas Champion, Tombatu F1 dan Victory, media yang digunakan meliputi arang sekam, pasir, dan batu bata, tissue, polibag $5 \mathrm{~kg}$, plastik putih, air, selang, jarum suntik serta nutrisi hidroponik farm A dan B. Alat yang digunakan adalah ember, pisau, parang, cangkul, meteran, botol aqua, wadah plastik, bambu ajir, gunting, kayu, paku, palu, gergaji, tempat pembakaran sekam (corong asap), timbangan analitik, cawan, tali rafia, kertas label, serta alat tulis menulis.

Penelitian ini menggunakan Rancangan Acak Lengkap (RAL) pola faktorial. Faktor yang diteliti yaitu varietas tomat (V) dan media tanam (M) yang masing-masing terdiri dari tiga taraf. Faktor pertama adalah varietas tomat (V), terdiri dari Champion, Tombatu F1 dan Victory. Faktor kedua adalah media tanam (M), terdiri dari arang sekam, pasir dan batu bata.

Rumah plastik yang dibuat dalam penelitian ini memiliki luas $5 \times 8 \mathrm{~m}$ dengan tinggi $2,5 \mathrm{~m}$. Suhu rumah plastik berkisar antara $28-34^{\circ} \mathrm{C}$ diukur dengan menggunakan termometer. Pem-buatan arang sekam dilakukan dengan cara membuat bara api yang kemudian ditutup dengan cerobong asap, sekam yang masih mentah dituang di sekeliling lingkaran cerobong. Apabila di bagian bawahnya sudah terlihat menghitam, sekam dibalik-balik agar hitamnya merata, kemudian dipindahkan ke wadah lain lalu disiram dengan air sambil terus diaduk. Hal ini bertujuan agar arang sekam tidak menjadi abu.

Media pasir dibersihkan terlebih dahulu dengan cara dicuci di dalam ember sambil diaduk-aduk, kemudian airnya dibuang sampai air tidak terlihat berwarna kecoklatan dan berbusa, kemudian ditiriskan. Media tanam berikutnya adalah batu bata, dimana batu bata dihancurkan sampai berukuran kecil yaitu mulai $2-10 \mathrm{~mm}$.

Benih tomat disemai pada wadah persemaian yang sudah dicampur tanah, pasir, dan arang sekam dengan perbandingan 1:1:1. Bibit dipindah saat berumur 20 hari setelah tanam ke dalam polibag ukuran $5 \mathrm{~kg}$ yang telah dipersiapkan. Polibag tersebut diletakkan sesuai rancangan di dalam rumah plastik. Pemindahan tanaman dilakukan dengan membongkar bibit di wadah semai, kemudian akar dicuci hingga bersih lalu ditanam pada lubang tanam yang telah dibuat pada polibag.

Pupuk yang diberikan berupa pupuk khusus untuk tanaman hidroponik yaitu Hydroponik farm (Good plant) yang terdiri dari nutrisi hidroponik A dan B. Pada fase vegetatif dosis yang dibutuhkan untuk sekali aplikasi nutrisi hidroponik A dan B masing-masing 10 $\mathrm{g} / 2$ liter air, nutrisi A dan $\mathrm{B}$ dicampur sehingga menjadi 20g.2 liter-1 air untuk keseluruhan tanaman. Pupuk diberikan sejumlah $3 \mathrm{ml}$ per tanaman dengan jumlah pemberian sebanyak 4 kali dalam sehari. Pada fase generatif, nutrisi 
yang diberikan sebanyak $4 \mathrm{ml}$ per tanaman dengan frekuensi pemberian 2 kali dalam sehari.

Pemeliharaan meliputi penyiraman, penyiangan, pengendalian hama dan penyakit. Pemanenan dilakukan pada umur 70 hari setelah tanam (HST), selanjutnya dilakukan setiap 3 hari sekali dengan interval waktu pemanenan selama 2 bulan. Pengamatan dilakukan terhadap organorgan generatif meliputi jumlah bunga per dompolan, jumlah dompolan per tanaman, diameter buah, panjang buah dan berat buah per satuan.

\section{Hasil dan Pembahasan}

Dompolan Per Tanaman, Jumlah Bunga Per Dompolan dan Jumlah Buah Per Dompolan
Hasil pengamatan menunjukkan bahwa jumlah dompolan per tanaman, jumlah bunga per dompolan dan jumlah buah per dompolan terbanyak dijumpai pada varietas Victory dengan nilai masing-masing 16,28 dompolan, 8,96 bunga dan 6,55 buah. Namun hal ini tidak berbeda nyata dengan varietas Tombatu F1. Hasil pengamatan juga menunjukkan bahwa media tanam yang dipergunakan tidak berpengaruh nyata terhadap jumlah dompolan per tanaman, jumlah bunga per dompolan dan jumlah buah per dompolan. Namun media tanam yang terbaik terhadap jumlah dom-polan per tanaman dan jumlah buah per dompolan adalah media pasir sedangkan pemakaian media tanam batu bata mampu menghasilkan jumlah bunga per dompolan terbanyak.

Tabel 1. Rata-rata jumlah dompolan per tanaman, jumlah bunga per dompolan dan jumlah buah per dompolan akibat pengaruh varietas dan media tanam

\begin{tabular}{|c|c|c|c|}
\hline Perlakuan & $\begin{array}{c}\text { Jumlah Dompolan per } \\
\text { Tanaman }\end{array}$ & $\begin{array}{c}\text { Jumlah Bunga per } \\
\text { Dompolan }\end{array}$ & $\begin{array}{c}\text { Jumlah Buah per } \\
\text { Dompolan }\end{array}$ \\
\hline \multicolumn{4}{|c|}{ 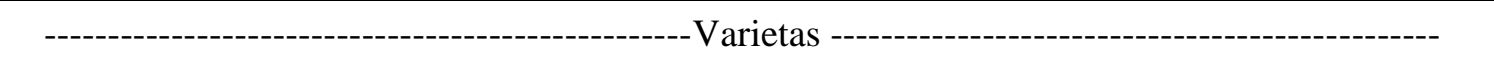 } \\
\hline Champion & $12,50 \mathrm{~b}$ & $7,76 \mathrm{a}$ & $4,98 \mathrm{~b}$ \\
\hline Tombatu F1 & $14,72 \mathrm{ab}$ & $7,99 \mathrm{a}$ & $6,14 \mathrm{ab}$ \\
\hline Victory & $16,28 \mathrm{a}$ & $8,96 \mathrm{a}$ & $6,55 \mathrm{a}$ \\
\hline BNT 0,05 & 3,8 & 3,09 & 1,57 \\
\hline \multicolumn{4}{|c|}{ 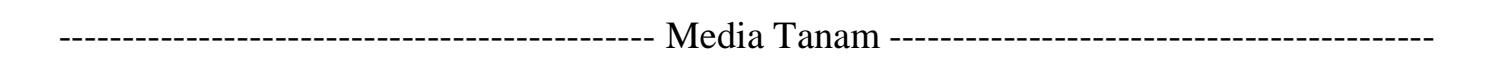 } \\
\hline Arang sekam & $14,72 \mathrm{a}$ & $8,05 \mathrm{a}$ & $5,61 \mathrm{a}$ \\
\hline Pasir & $14,89 \mathrm{a}$ & $8,04 \mathrm{a}$ & $6,23 \mathrm{a}$ \\
\hline Batu bata & $13,89 \mathrm{a}$ & $8,61 \mathrm{a}$ & $5,83 \mathrm{a}$ \\
\hline BNT 0,05 & 3,8 & 3,09 & 1,57 \\
\hline
\end{tabular}

Keterangan: Angka yang diikuti oleh huruf yang sama pada kolom yang sama tidak berbeda nyata menurut uji BNT taraf 0.05

Berdasarkan deskripsi masing-masing varietas diketahui bahwa varietas Champion memiliki jumlah bunga dan buah terbanyak dibandingkan varietas yang lain yang digunakan. Namun hasil penelitian memperlihatkan bahwa varietas Victory lebih unggul dalam jumlah bunga dan buah dibandingkan varietas Champion dan Tombatu F1. Hal ini membuktikan bahwa karakter organ generatif dari suatu varietas bukan saja ditentukan oleh faktor genotip saja tetapi juga ditentukan oleh faktor lingkungan. Menurut Darjanto dan Satifah (1984), pembentukan bunga adalah peralihan pertumbuhan dari fase vegetatif ke fase generatif. Peralihan dari fase vegetatif ke fase generatif sebagian ditentukan oleh faktor genotip (sifat turun temurun) atau faktor dalam dan sebagian lagi ditentukan oleh faktor luar seperti suhu, cahaya, kelembaban dan pemupukan. Faktor luar yang paling berpengaruh terhadap pembentukan bunga tomat adalah suhu, untuk pembentukan bunga yang baik, tomat memerlukan suhu $23^{\circ} \mathrm{C}$ pada siang hari dan suhu $17^{\circ} \mathrm{C}$ pada malam hari. Batas suhu yang paling rendah bagi tanaman tomat di waktu malam adalah $12^{\circ} \mathrm{C}$.

Tabel pengamatan juga menunjukkan bahwa persentase bunga yang menjadi buah pada 
varietas Victory juga lebih besar dibandingkan dengan Champion dan Tombatu F1. Hal ini disebabkan karena varietas Victory memiliki adaptasi yang lebih baik terhadap kekeringan. Salah satu penyebab kekeringan pada tanaman tomat karena suhu yang tinggi pada rumah kaca sehingga meningkatkan laju traspirasi. Hal ini secara tidak langsung akan mengakibatkan hilang-nya sejumlah air yang terdapat di dalam jaringan tanaman. Sebahagian besar tanaman akan meng-gugurkan organ tubuhnya termasuk bunga sebagai bentuk adaptasi terhadap kekeringan. Rubatzky dan Yamaguchi (1999) menyatakan bahwa suhu siang $25-30^{\circ} \mathrm{C}$ dengan suhu malam $16-20^{\circ} \mathrm{C}$ adalah suhu yang optimum untuk pertumbuhan dan pembungaan. Menurut Wijayanti dan Susila (2013), suhu yang relatif tinggi dan (RH) yang relatif rendah menyebabkan bunga mudah gugur. Suhu udara di dalam greenhouse yang cenderung tinggi mengakibatkan terganggunya proses pembungaan.

\section{Diameter Buah, Panjang Buah dan Berat Buah Persatuan}

Tabel 2 menunjukkan bahwa varietas Tombatu F1 memiliki diameter buah, panjang buah dan berat buah per satuan terbaik dengan nilai masing-masing $60,72 \mathrm{~mm}, 81,90 \mathrm{~mm}$ dan 38,39 g. Jenis media tanam tidak berpengaruh nyata terhadap diameter buah, panjang buah dan berat buah per satuan, namun media tanam batu bata memberikan respon yang terbaik terhadap panjang dan berat buah per satuan.

Besarnya diameter dan panjang buah berkaitan dengan proses pembelahan sel yang terjadi dalam tanaman selama pertumbuhan dan perkembangannya, termasuk pembelahan sel dalam buah. Hal ini sesuai dengan pendapat Gardner et al. (1991), bahwa pertumbuhan suatu organ termasuk buah, dapat melalui tahap pasca fertilisasi yang menyebabkan ukuran buah meningkat karena terjadi pembelahan sel.

Tabel 2. Rata-rata diameter buah, panjang buah dan berat buah persatuan akibat pengaruh varietas dan media tanam

\begin{tabular}{lccc}
\hline \multicolumn{1}{c}{ Perlakuan } & $\begin{array}{c}\text { Diameter Buah } \\
(\mathrm{mm})\end{array}$ & Panjang Buah $(\mathrm{mm})$ & $\begin{array}{c}\text { Berat buah } \\
\text { persatuan }(\mathrm{g})\end{array}$ \\
\hline \multicolumn{4}{c}{ Varietas } \\
\hline Champion & $59.96 \mathrm{a}$ & $77.75 \mathrm{a}$ & $37,55 \mathrm{a}$ \\
Tombatu F1 & $60.72 \mathrm{a}$ & $81.90 \mathrm{a}$ & $38,95 \mathrm{a}$ \\
Victory & $51.18 \mathrm{~b}$ & $59.10 \mathrm{~b}$ & $22,35 \mathrm{~b}$ \\
BNT 0.05 & 7,69 & 9,91 & 6,808 \\
\hline \multicolumn{5}{c}{ Media Tanam } \\
\hline Arang sekam & $56.16 \mathrm{a}$ & $71.19 \mathrm{a}$ & $31,39 \mathrm{a}$ \\
Pasir & $57.24 \mathrm{a}$ & $74.53 \mathrm{a}$ & $32,35 \mathrm{a}$ \\
Batu bata & $58.47 \mathrm{a}$ & $73.03 \mathrm{a}$ & $35,11 \mathrm{a}$ \\
\hline BNT 0.05 & 7,69 & 9,91 & 6,808 \\
\hline
\end{tabular}

Keterangan: Angka yang diikuti oleh huruf yang sama pada kolom yang sama tidak berbeda nyata menurut uji BNT taraf 0.05

\section{Kesimpulan}

Varietas Victory memberikan jumlah dompolan per tanaman, jumlah bunga per dompolan dan jumlah buah per dompolan terbanyak dibandingkan varietas Tombatu F1 dan Champion. Namun varietas Tombatu F1 memiliki diameter buah, panjang buah dan berat buah persatuan terbaik. Media tanam yang digunakan tidak memberikan pengaruh terhadap karakter organ-organ generatif tanaman tomat yang diamati.

\section{Saran}

Untuk meningkatkan produksi tomat dengan teknik hidroponik perlu kiranya menggunakan varietas-varietas unggul seperti Victory dan Tombatu F1 disertai dengan pengontrolan terhadap suhu dan kelembaban. 
Perlu kiranya dilakukan pengujian lebih lanjut terhadap media tanam yang lain dalam teknik budidaya secara hidroponik.

\section{Daftar Pustaka}

Darjanto dan Satifah, S. 1984. Pengetahuan Dasar Biologi Bunga dan Teknik Penyerbukan Silang Buatan. PT. Gramedia. Jakarta.

Direktorat Perbenihan dan Sarana Produksi. 2010. Standar Prosedur Operasional Budidaya Tomat. www.distan.pemdadiy.go.id/

images/stories/Teknologi/spo\%20tomat.pd f. [12 Maret 2013].

Gardner, F.P., R.B. Pearce, dan R.I. Mitchell. 1991. Fisiologi Tanaman Budidaya. UI
Press. Jakarta.

Kementerian Pertanian. 2013. Produksi Tomat Menurut Provinsi, 2009-2013. http://www. pertanian.go.id/ap_pages/mod/datahorti. [12 Maret 2013].

Rubatzky, V. E. dan M. Yamaguchi. 1999. Sayuran Dunia 1: Prinsip, Produksi dan Gizi. (terjemahan). ITB Press. Bandung.

Trisnawati, Y. dan A.I. Setiawan. 2005. Tomat Budidaya Secara Komersial. Penebar Swadaya, Jakarta.

Wijayanti, E. dan A. D. Susila. 2013. Pertumbuhan dan Produksi Dua Varietas Tomat (Lycopersicon esculentum Mill.) secara Hidroponik dengan Beberapa Komposisi Media Tanam. Buletin Agrohorti.1(1) : 104-112. 